\title{
Cardiovascular activity in migraine patients: Influence of age and headache chronification
}

\author{
O Grosu*, S Odobescu, I Moldovanu, L Rotaru \\ From The European Headache and Migraine Trust International Congress \\ London, UK. 20-23 September 2012
}

\section{Introduction}

Heart rate variability (HRV) is a useful tool to evaluate cardiovascular activity in different pathologies including migraine. Reduced HRV over 24 hours predicts increase in cardio-vascular morbidity.

\section{Objectives}

To evaluate and analyze cardiovascular activity by mean of HRV in migraine patients and elucidate the influence of age and chronification.

\section{Methods}

Study group consisted of 65 pts with migraine: 40 pts with chronic (CM) and 25 pts with episodic migraine (EM), mean age $47.7 \pm 11.29(\mathrm{CM})$ and $47.6 \pm 12.6$ years $(\mathrm{EM})$. All the patients underwent 24-hour ambulatory ECG monitoring with evaluation of HRV. The analyzed time domain parameters were: VAR, CBBP, avNN, SDNN, RRNN, SDANN, SDNN index, RMSSD and pNN50 \% and frequency domain parameters: LF, HF and VLF. All expressed as mean, day time and night time values.

\section{Results}

CM patients had increased VAR $(946.8 \pm 433.4$ vs. 785.6 $\pm 214.4, \mathrm{p}<0.05)$, SDNN index $(53,1 \pm 17.8$ vs. $45.7 \pm 8.6$, $\mathrm{p}<0.05)$ and VLF $(2013.05 \pm 1151.5$ vs. $1567.32 \pm 526.6$, $\mathrm{p}<0.05)$. In the middle age (40-50 years old) EM patients had increased Heart rate $(84.8 \pm 8.6$ vs. $77.5 \pm 7.9, \mathrm{p}<0.05)$ and CM patients increased: avNN (837.6 \pm 93.7 vs. 787.0 $\pm 78.3, \mathrm{p}<0.05)$, SDNN index $(60.1 \pm 15.0$ vs. $45.8 \pm 5.63$, $\mathrm{p}<0.05)$ and VLF $(2724.4 \pm 1449.1$ vs. $1618.2 \pm 509.9$, $\mathrm{p}<0.05)$. In the advanced age (50-59 years old) $\mathrm{CM}$ patients had increased HF $(30.6 \pm 13.1$ vs. $19.7 \pm 11.9$, $\mathrm{p}<0.05)$. Compared between groups (EM40-50 vs. EM 50-59) - EM50-59 patients had reduced pNN50\% and
CBBP and CM 50-59 patients had reduced pNN50\%, SDNN index, VLF, LF, HF but increased HF(\%). Conclusions CM patients presented an increased HRV and parasympathetic activity compared with EM in whole study sample and in the 40-50 age group but just parasympathetic hyperactivity in the 50-59 age groups. Older CM patients presented more reduction in total HRV, sympathetic and parasympathetic influence (day time), except HF (\%) night time which reflect strong vagal influence probably as a consequence of chronification process.

Published: 21 February 2013

\section{Reference}

1. Camm AJ, Malik M, Bigger JT, Breithardt G, Cerutti S, Cohen RJ, Coumel P, Fallen EL, Kennedy HL, Kleiger RE, Lombardi F, Malliani A, Moss AJ, Rottman JN, Schmidt G, Schwartz PJ, Singer DH: "Heart rate variability: standards of measurement, physiological interpretation, and clinical use (Task Force of the European Society of Cardiology and the North American Society of Electrophysiology)". Circulation 1996, 93:1043-1065.

doi:10.1186/1129-2377-14-S1-P139

Cite this article as: Grosu et al:: Cardiovascular activity in migraine patients: Influence of age and headache chronification. The Journal of Headache and Pain 2013 14(Suppl 1):P139.

Submit your manuscript to a SpringerOpen ${ }^{\bullet}$ journal and benefit from:

- Convenient online submission

- Rigorous peer review

- Immediate publication on acceptance

- Open access: articles freely available online

- High visibility within the field

- Retaining the copyright to your article

Submit your next manuscript at $>$ springeropen.com 